\title{
Life history patterns of some selected endemic freshwater fish species inhabiting two major river basins of Sri Lanka
}

\author{
R.R.A. Ramani Shirantha*†, M. Jayantha S. Wijeyaratne and Upali S. Amarasinghe \\ Department of Zoology and Environmental Management, University of Kelaniya, Kelaniya \\ 11600, Sri Lanka
}

$\dagger$ Present address: Inland Aquatic Resources and Aquaculture Division, National Aquatic Resources Research \& Development Agency, Crow Island, Colombo 15, Sri Lanka
* Corresponding author (ramanishirantha@gmail.com)
iD https://orcid.org/0000-0001-5270-9175

\begin{abstract}
Life history information on six endemic fish species namely Belontia signata, Pethiya cumingii, P. nigrofasciata, Puntius titteya, Rasboroides vaterifloris and Garra ceylonensis inhabiting the Kalu Ganga and Kelani Ganga river basins in Sri Lanka was evaluated. The growth constant of the fish species showed a positive relationship with the river order where they inhabited. The length at 50\% maturity $\left(\mathrm{L}_{\mathrm{m}}\right)$ significantly correlated with the asymptotic length and growth constant indicating that fishes with slow growth become sexually mature late in their life cycles. The optimal lengths for sustainable exploitation of the fish species studied were significantly $(\mathrm{p}<0.01)$ correlated with asymptotic lengths and lengths at $50 \%$ maturity whereas negatively correlated with natural mortality. This analysis indicated that $\mathrm{L}_{\mathrm{m}}$ was a foremost function of size of fish apart from maximum length observed ( $\mathrm{L}_{\max }$, ) and that $\mathrm{L}_{\mathrm{m}}$ and $\mathrm{L}_{\max }$ can be used as deterministic variables for quantifying optimal size of exploitation for sustainability and conservation of fish populations.
\end{abstract}

Keywords: biodiversity conservation, growth parameters, mortality parameters, length at $50 \%$ maturity, natural mortality

\section{INTRODUCTION}

Life-history patterns of fish that include speciesspecific growth, mortality and reproductive effort are evolved as a result of complex array of selective forces that are imposed on a species by its environment (Breder and Rosen 1966; Wootton 1998; King 2007). In tropical fish communities, life history patterns are extensive due to their high diversity in morphological and ecological attributes (Kortmulder 1987; Welcomme 2001). In some species, life-history patterns significantly vary in different populations, including those living at different latitudes (Jonsson and L'AbeeLund 1993; Baker 1994; Baker et al. 2015).

Apart from the attempts to evaluate the relationships between life-history patterns of fish and environmental conditions (Southwood 1988; Roff 1992; Stearns 1992; Charnov 1993), several empirical relationships have been developed for many exploited fish stocks mainly to quantify important population parameters required for stock assessment (Taylor 1958; Beverton and Holt 1959; Beverton 1963; Pauly 1980; Vetter 1988; Jensen 1996; Hart and Russ 1996; Ault et al. 1998; Jennings et al. 1998).

Since it is a fact that many tropical riverine fish communities are under threat due to various natural and anthropogenic factors (Dudgeon 2003), conservation strategies are imperative in many countries in tropical Asia. In countries like Sri Lanka, where many endemic freshwater riverine fish species are under threat due to habitat degradation and unrestrained exploitation for ornamental fish trade (Amarasinghe et al. 2006; MOE 2012) as well as damming of rivers and streams for hydropower development (Silva and Silva 2015), empirical relationships between life history parameters and optimal exploitation levels are useful for introducing effective conservation strategies. In the present study, an attempt was therefore made to evaluate life history relationships in growth and maturity of selected endemic riverine fish species in Sri Lanka. 


\section{R.R.A.R. Shirantha et al.}

\section{MATERIALS AND METHODS}

One endemic anabantid species (Belontia signata), and five endemic cyprinid species namely Pethia cumingii, $P$. nigrofasciata, Puntius titteya, Rasboroides vaterifloris and Garra ceylonensis in the Kalu Ganga and Kelani Ganga river basins were sampled once in two months from October 1998 to September 2000 from 15 sampling sites from each river basin (Fig. 1) using a cast net of mesh size $1.0 \mathrm{~cm}$. Two sampling sites in Kalu Ganga river basin (KA9 and KA10; Fig. 1) however, were subsequently abandoned as these two sampling sites were destroyed during the construction phase of a medium-scale hydropower development project, Kukule Ganga hydropower project. For ethical clearance, permission for conducting research was obtained from the University of Kelaniya, Sri Lanka and permission for catching fish from the wild was obtained from the Department of Wildlife Conservation. Number of specimens of each species sampled and size ranges of each species studied are given in Table 1. All six species studied were small in body size (Table 1), and as such, it was assumed that none of the species perform long-distance migration. Consequently, each sampling site in the two rivers was assumed to be occupied by localized populations of the six species studied.

\section{Kelani Ganga River Basin}

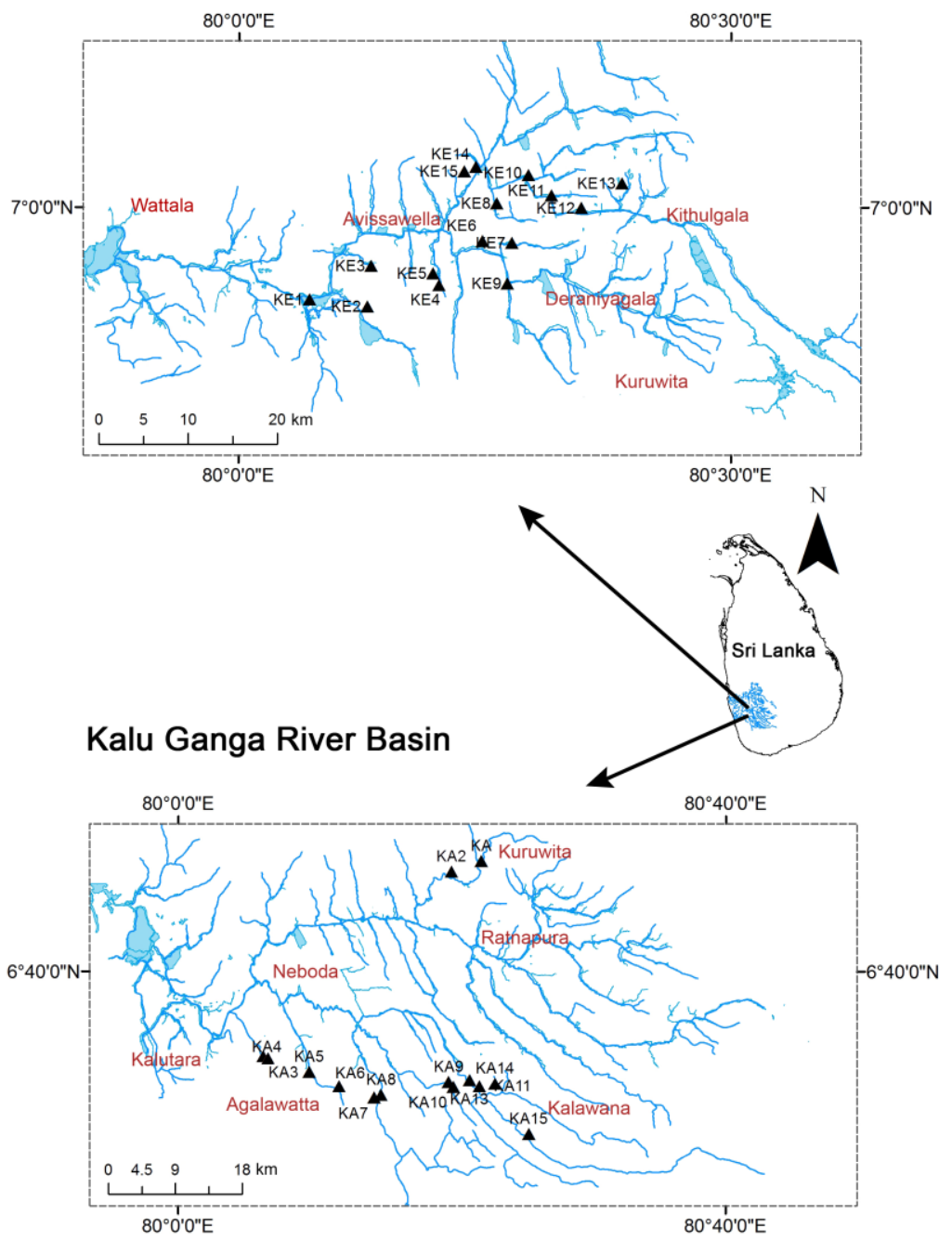

Fig. 1 Maps of Kalu Ganga and Kelani Ganga river basins showing the sampling sites. 


\section{R.R.A.R. Shirantha et al.}

Table 1 Number of specimens in each species sampled for length-frequency analysis, and size ranges (total length; TL) in the sampling sites of two river basins during the study period. Sampling sites are as given in Figure 1.

\begin{tabular}{|c|c|c|c|c|c|}
\hline \multirow[t]{2}{*}{ Species } & \multicolumn{2}{|c|}{$\begin{array}{l}\text { Kelani Ganga river } \\
\text { basin }\end{array}$} & \multicolumn{2}{|c|}{ Kalu Ganga river basin } & \multirow[t]{2}{*}{ TL range $(\mathrm{cm}$} \\
\hline & Site & Nos & Site & Nos & \\
\hline \multirow[t]{4}{*}{ Belontia signata } & $\mathrm{KE} 4$ & 412 & KA 1 & 370 & $2.7-10.3$ \\
\hline & KE 5 & 278 & KA 2 & 90 & $2.2-9.5$ \\
\hline & KE 10 & 128 & KA 4 & 312 & $2.2-7.8$ \\
\hline & KE 15 & 528 & & & $2.2-9.6$ \\
\hline \multirow[t]{5}{*}{ Pethia cumnigii } & KE 6 & 213 & KA 8 & 315 & $2.4-6.1$ \\
\hline & KE 11 & 182 & KA 5 & 150 & $3.1-5.4$ \\
\hline & KE 12 & 267 & & & $2.7-5.6$ \\
\hline & KE 13 & 213 & & & $3.0-5.6$ \\
\hline & KE 14 & 129 & & & $2.6-5.5$ \\
\hline \multirow[t]{5}{*}{ Pethia nigrofasiata } & KE 10 & 196 & KA 6 & 185 & $2.4-5.8$ \\
\hline & KE 6 & 313 & KA 7 & 233 & $1.2-6.2$ \\
\hline & KE 7 & 197 & KA 13 & 471 & $2.5-6.0$ \\
\hline & & & KA 14 & 159 & $3.2-5.7$ \\
\hline & & & KA 15 & 247 & $3.0-6.4$ \\
\hline \multirow[t]{6}{*}{ Puntius titteya } & $\mathrm{KE} 2$ & 178 & KA 3 & 261 & $1.2-5.0$ \\
\hline & $\mathrm{KE} 4$ & 312 & KA 4 & 201 & $1.7-5.0$ \\
\hline & KE 5 & 210 & & & $2.0-4.8$ \\
\hline & KE 8 & 186 & & & $2.1-4.8$ \\
\hline & KE 9 & 312 & & & $1.8-5.0$ \\
\hline & KE 15 & 437 & & & $2.0-4.3$ \\
\hline Rasboroides vaterifloris & & & KA 7 & 313 & $3.0-5.0$ \\
\hline Garra ceylonensis & KE 6 & 92 & KA 1 & 276 & $4.2-12.5$ \\
\hline
\end{tabular}

Length measurements of individual specimens were taken in situ and the fish were released back to the habitat immediately. During each sampling visit, only two specimens from each species were taken randomly for determination of length at $50 \%$ maturity albeit inadequacy of sample sizes for comprehensive studies on reproductive biology. This precautionary approach was adopted to comply with scientific ethics not to damage biological diversity of threatened species through sampling.

Length frequency data (Total length in $\mathrm{mm}$ ) of the samples collected from October 1998 to September 2000 for 5 species (except $R$. vaterifloris) from 14 sites in Kelani Ganga river basin and for all 6 species from 11 sites in Kalu Ganga river basin (Table 1) were analysed using ELEFAN routine in the FiSAT software package (Gayanilo et al. 2005). Here, for each species, the root value of asymptotic length
$\left(\mathrm{L}_{\infty}\right)$ estimated from the maximum length observed/0.95 as described by Pauly (1983) was used to estimate $\mathrm{L}_{\infty}$ and growth constant $(\mathrm{K})$. Total mortality $(\mathrm{Z})$ and natural mortality $(\mathrm{M})$ coefficients were estimated from lengthconverted catch curve method (Pauly 1984) and Pauly's (1980) empirical equation respectively. Using growth parameters $\left(\mathrm{L}_{\infty}\right.$ and $\left.\mathrm{K}\right), \mathrm{Z}$ and $\mathrm{M}$, relative yield-per-recruit (Beverton and Holt 1964) was determined for the array of exploitation rates $(E=F / Z)$ for different lengths at first capture to estimate the optimal length at first capture $\left(\mathrm{L}_{\mathrm{opt}}\right)$ for long-term sustainable exploitation.

Each specimen was dissected open, eviscerated and the gonadal maturity stage was identified using the maturity scale described by Wijeyaratne and Costa (1987). The lengths at $50 \%$ maturity $\left(\mathrm{L}_{\mathrm{m}}\right)$ of each species was estimated from a plot of percentage maturity against fish length (Burd 1962). In the present 


\section{R.R.A.R. Shirantha et al.}

analysis, as mentioned above, only two specimens were taken from each species in each sampling visit. This caused inadequacy of sample size, and as such, $\mathrm{L}_{\mathrm{m}}$ was estimated only for 10 populations with adequate samples.

Relationship between natural mortality coefficient $(\mathrm{M})$ and the longevity $\left(\mathrm{t}_{\max }\right)$ of the fish species studied at different sites was assessed using $t_{\max }$ estimated using the following equation (Pauly 1983).

$$
\mathrm{t}_{\max }=3 / \mathrm{K}
$$

where $\mathrm{K}=$ growth constant $\left(\right.$ year $\left.^{-1}\right)$.

Mean length at $50 \%$ maturity $\left(\mathrm{L}_{\mathrm{m}}\right)$ of each fish species studied was related to $\mathrm{L}_{\infty}$ for $\mathrm{Ln}$ transformed data using linear regression. Relationship between $\mathrm{K}$ and $\mathrm{L}_{\mathrm{m}}$ was also determined using linear regression.

The relationship between $\mathrm{L}_{\mathrm{opt}}$ and $\mathrm{L}_{\infty}$ of each fish species studied was also determined for $\mathrm{Ln}$ transformed data. Similarly the relationship of $\mathrm{L}_{\mathrm{opt}}$ and $\mathrm{L}_{\mathrm{m}}$ was also determined for each fish species. Natural mortality (M) was related to $\mathrm{L}_{\mathrm{opt}}$ for the fish species studied.

\section{RESULTS}

Mean length at $50 \%$ maturity $\left(\mathrm{L}_{\mathrm{m}}\right)$ of fish species studied showed a negative linear relationship with their growth constant (Fig. 2A). The natural mortality coefficients (M) of fish species studied inversely correlated with their longevity $\left(\mathrm{t}_{\max }\right)$ (Fig. $2 \mathrm{~B}$ ). $\mathrm{L}_{\mathrm{m}}$ of the fish species studied exhibited a significant positive linear relationship $(\mathrm{p}<0.01)$ with $\mathrm{L}_{\infty}$ (Fig. $\left.2 \mathrm{C}\right)$ indicating that the length at $50 \%$ maturity is a foremost function of size of fish. $\mathrm{L}_{\mathrm{opt}}$ is positively related to $\mathrm{L}_{\infty}$ (Fig. $3 \mathrm{~A}$ ), to $\mathrm{L}_{\mathrm{m}}$ (Fig. 3B), and negatively to $\mathrm{M}$ (Fig. 3C) showing that the life history parameters can be utilized for determining optimal exploitation strategies. Regression equations for all of these relationships are given in Table 2.

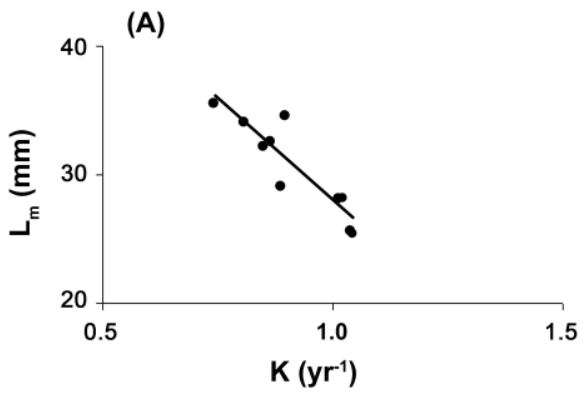

(B)
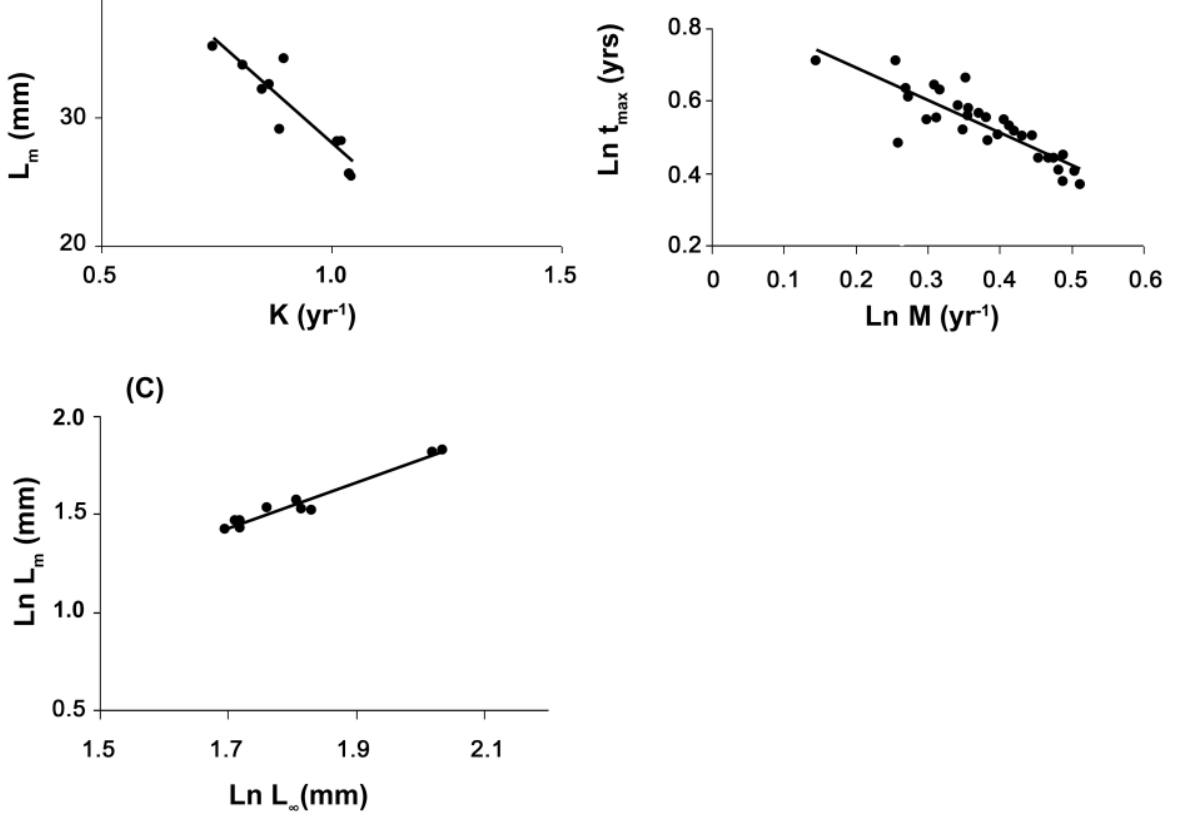

Fig. 2 Relationship between (A) growth constant $(\mathrm{K})$ and length at 50\% maturity $\left(\mathrm{L}_{\mathrm{m}}\right)$; (B) natural mortality coefficient and longevity $\left(\mathrm{t}_{\max }\right)(\mathrm{C})$ asymptotic length $\left(\mathrm{L}_{\infty}\right)$ and length at $50 \%$ maturity $\left(\mathrm{L}_{\mathrm{m}}\right)$ of fish species studied in the Kalu Ganga and Kelani Ganga river basins. 

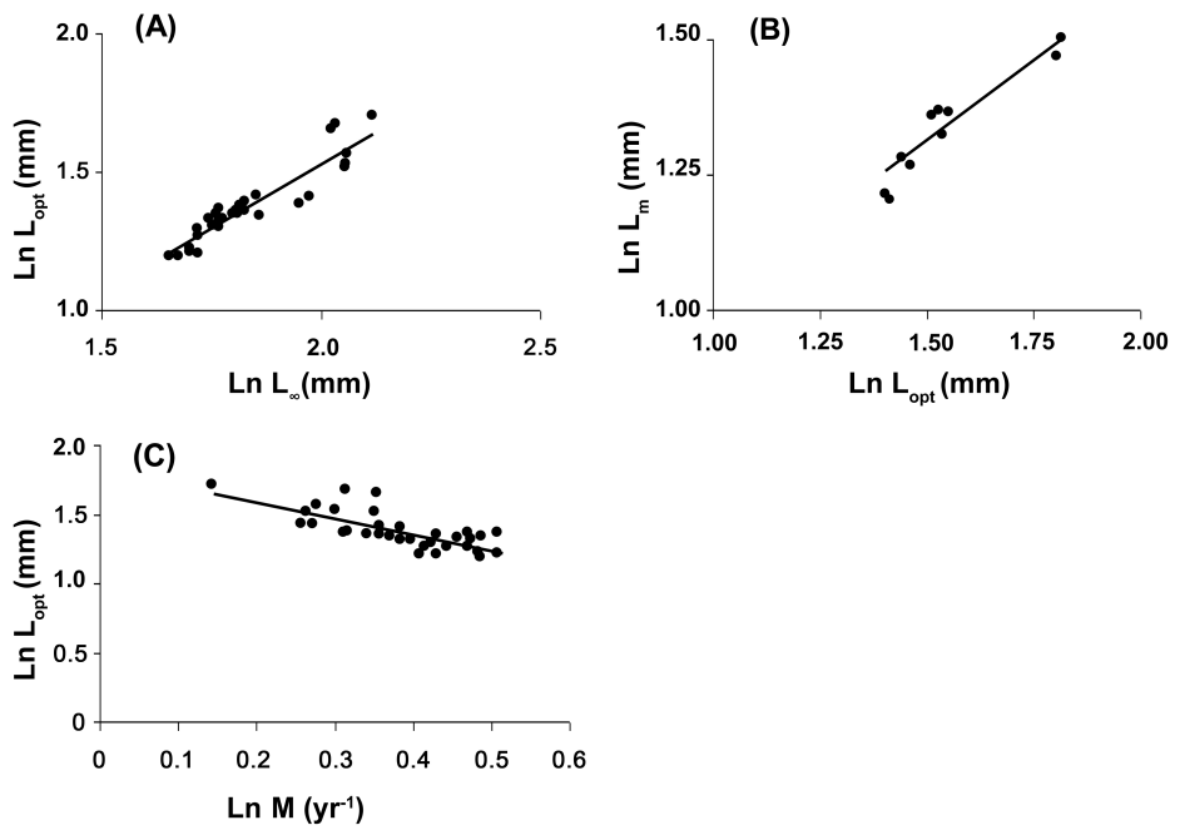

Fig. 3 Relationships of length at maximum possible relative yield-per-recruit ( $\left.\mathrm{L}_{\mathrm{opt}}\right)$ (A) to asymptotic length, (B) to length at 50\% maturity, and (C) to natural mortality of the fish species studied in the Kalu Ganga and Kelani Ganga river basins.

Table 2 Regression equations for different relationships of life history parameters of cyprinid species studied.

\begin{tabular}{|c|c|c|c|c|c|}
\hline Parameters & $\mathrm{n}$ & Regression Equation & $\begin{array}{l}\text { Correlation } \\
\text { coefficient }\end{array}$ & Significant level & Figure No. \\
\hline $\mathrm{K}$ and $\mathrm{L}_{\mathrm{m}}$ & 10 & $\mathrm{~L}_{\mathrm{m}}=-31.67 \mathrm{~K}+59.645$ & -0.880 & $\mathrm{p}<0.01$ & Fig. $2 \mathrm{~A}$ \\
\hline$M$ and $t_{\max }$ & 33 & $\operatorname{Ln} t_{\max }=-0.898 * \operatorname{Ln} M+0.867$ & -0.861 & $\mathrm{p}<0.01$ & Fig. 2B \\
\hline $\mathrm{L}_{\infty}$ and $\mathrm{L}_{\mathrm{m}}$ & 10 & $\operatorname{Ln}\left(\mathrm{L}_{\mathrm{m}}\right)=1.166 * \operatorname{Ln} \mathrm{L}_{\infty}-0.562$ & 0.981 & $\mathrm{p}<0.01$ & Fig. 2C \\
\hline $\mathrm{L}_{\infty}$ and $\mathrm{L}_{\mathrm{opt}}$ & 33 & $\mathrm{Ln} \mathrm{L}_{\mathrm{opt}}=0.933 * \mathrm{Ln} \mathrm{L}_{\infty}-0.346$ & 0.933 & $\mathrm{p}<0.01$ & Fig. 3A \\
\hline $\mathrm{L}_{\mathrm{m}}$ and $\mathrm{L}_{\mathrm{opt}}$ & 10 & $\mathrm{Ln} \mathrm{L}_{\mathrm{opt}}=0.594 * \mathrm{Ln} \mathrm{L}_{\mathrm{m}}+0.419$ & 0.953 & $\mathrm{p}<0.01$ & Fig. 3B \\
\hline $\mathrm{M}$ and $\mathrm{L}_{\mathrm{opt}}$ & 33 & $\mathrm{Ln} \mathrm{L}_{\mathrm{opt}}=-1.148^{*} \operatorname{Ln} \mathrm{M}+1.81$ & -0.736 & $\mathrm{p}<0.01$ & Fig. 3C \\
\hline
\end{tabular}

$\mathrm{L}_{\infty}$ - asymptotic length (mm); K- growth constant $\left(\mathrm{yr}^{-1}\right) ; \mathrm{M}$ - natural mortality $\left(\mathrm{yr}^{-1}\right) ; \mathrm{t}_{\max }$ - potential longevity (yrs); $\mathrm{L}_{\mathrm{opt}}$ - optimal length (mm); $\mathrm{L}_{\mathrm{m}}$ - length at $50 \%$ maturity $(\mathrm{mm})$.

\section{DISCUSSION}

Despite the widespread misconception among conservationists and environmentalists that preservation is conservation, attributes of biological conservation are recognized as preservation, maintenance, enhancement, restoration and sustainable use (Miththapala 2015). It is also alarming that in the ornamental fish export industry in Sri Lanka, annually over 63,000 individuals of wild-caught freshwater fishes are exported and over $63 \%$ of them are endemic species (Fernando et al. 2013). This necessitates strategies for sustainable use of wild-caught fish resources. Present study showed that the life history parameters of fish species studied were interrelated making possible empirical assessment of the status of the fish populations in the two river basins for their sustainable exploitation.

Growth constant $(\mathrm{K})$ of von Bertalanffy growth formula (VBGF) is known to be closely linked to the longevity in fish (Beverton and Holt 1959; Gayanilo and Pauly 1997). In nature, the oldest fish of a stock grow about $95 \%$ of their asymptotic 


\section{R.R.A.R. Shirantha et al.}

length (Taylor 1958; Beverton 1963). The relationship between $\mathrm{L}_{\infty}$ and $\mathrm{t}_{\max }$ expressed as $\mathrm{t}_{\max }=$ $\left\{\ln \left[1-\left(\mathrm{L}_{\max } / \mathrm{L}_{\infty}\right)\right] /-\mathrm{K}\right\}-\mathrm{t}_{\mathrm{o}}$ according to VBGF (Gayanilo and Pauly 1997), can be simplified as $\mathrm{t}_{\max }=(2.9957 / \mathrm{K})+\mathrm{t}_{\mathrm{o}}$ ignoring $\mathrm{t}_{\mathrm{o}}$ value $\left(\mathrm{t}_{\max } \approx 3 / \mathrm{K}\right)$. Hence, inverse relationship of $\mathrm{t}_{\max }$ with natural mortality and positive relationship with $\mathrm{K}$ are justifiable.

The mean length at $50 \%$ maturity $\left(\mathrm{L}_{\mathrm{m}}\right)$ is an important management parameter to monitor whether there are sufficient mature individuals in the population at the length at first capture under the prevailing exploitation pattern. However, due to the inadequacy of sample sizes, $\mathrm{L}_{\mathrm{m}}$ of fish species were estimated for 10 populations of different species, because we were compelled to sample bare minimum of these endemic fish species to conform to scientific ethics. However, this limitation is thought to have compromised the findings of the study because the conclusions in the present study were based on regression relationships of $\mathrm{L}_{\mathrm{m}}$ with life history parameters. As $\mathrm{L}_{\mathrm{m}}$ of the fish species studied was significantly ( $p<0.01)$ correlated with $\mathrm{L}_{\infty}, \mathrm{L}_{\mathrm{m}}$ can be considered as a foremost function of a fish size, as evident from studies elsewhere (Alm 1959; Beverton and Holt 1959; Pauly 1984; Beverton 1992; Ault et al. 1998; Stamps et al. 1998; Jennings et al. 1998). Furthermore, as $\mathrm{L}_{\infty}$ can be approximated from maximum length observed/0.95 (Pauly 1983), maximum length observed $\left(\mathrm{L}_{\max }\right)$ can also be treated as a function of fish size.

The optimal lengths of the fish species studied were positively correlated with $\mathrm{L}_{\infty}$ and $\mathrm{L}_{m}$ while negatively correlated with $\mathrm{M}$ (Table 2$)(\mathrm{p}<0.01)$. Forese and Binohlan (2000) showed that in small fish populations, optimal length may be smaller than or equal to length at $50 \%$ maturity, whereas in large fish populations, optimal length is usually larger than length at 50\% maturity. This is an important factor especially in the reproductive strategies of small and short-lived fishes with high mortality rates. According to Figure 3C, natural mortality is inversely correlated with the optimal length in fish species studied. The practical utility of the present study is that the length at 50\% maturity, i.e., mean size of maturity and $\mathrm{L}_{\max }$ can be used as deterministic variables for quantifying optimal size of exploitation for sustainability and conservation of fish populations.
Although all species studied are legally protected in Sri Lanka, there appears to be a lacunae in law enforcement. According to Fernando et al. (2013), all freshwater fish species which have been exported from Sri Lanka annually for ornamental fish trade are wild-collected ones and majority of them are endemic species. Fernando et al. (2013) also mentioned that there were no exporters who practiced captive breeding. In addition, many endemic freshwater riverine fish species are known to be under threat due to habitat degradation (Amarasinghe et al. 2006; MOE 2012) and damming of rivers and streams mainly for small hydropower development projects (Silva and Silva 2015). Hence, the empirical relationships found in this study, which indicated that $\mathrm{L}_{\mathrm{m}}$ and $\mathrm{L}_{\max }$ have predictive power for determining optimal size of first capture, are of potential use for sustainable utilization of endemic fish species of economic value in ornamental fish trade. Furthermore, the spatial variation of life history patterns of fish species studied, not only between the two river basins, but also in different localities within each river basin, warrants these empirical relationships to be employed in spatial dimensions for conservation of fish biodiversity. Vila-Gispert and Moreno-Amich (2002), who studied life history patterns of 25 fish species inhabiting European freshwaters have shown that spectrum of life-history patterns was evident ranging from opportunistic life history style, with early maturity and small body size, to periodic life history style, with late maturity and large body size. These life history variants were shown to be with high concordance with basic life history patterns of species caused by universal trade-offs among life history variables. Under the same token, Mims et al. (2010) also have shown that life history patterns of freshwater fishes in North America can be placed in a tri-lateral continuum with three endpoint strategies defining the equilibrium (low fecundity, high juvenile survivorship), opportunistic and periodic life histories. The empirical relationships based on spatially variable life history patterns of fish species studied therefore are important for introducing effective conservation strategies. 


\section{R.R.A.R. Shirantha et al.}

\section{Acknowledgements}

The financial support provided by National Science Foundation of Sri Lanka (Grant Number: $\mathrm{RG} / 98 / \mathrm{MAB} / 03$ ) is gratefully acknowledged. Authors are thankful to Mr. R.P.K.C. Rajapakse, Department of Zoology and Environmental Management, University of Kelaniya for his assistance in preparing figures.

\section{REFERENCES}

Alm, G. 1959. Connection between maturity, size, and age in fishes. Report of the Institute of Freshwater Research Drottningholm 40: 1-145.

Amarasinghe, U.S., R.R.A.R. Shirantha and M.J.S. Wijeyaratne 2006. Some aspects of ecology of endemic freshwater fishes of Sri Lanka. pp. 113124. In. C.N.B. Bambaradeniya (ed.). The Fauna of Sri Lanka: Status of Taxonomy, Research and Conservation. The World Conservation Union, Sri Lanka and the Government of Sri Lanka. 308 pp.

Ault, J.S., J.A. Bohnsack and G.A. Meester 1998. A retrospective (1979-1996) multispecies assessment of coral reef fish stocks in the Florida Keys. Fishery Bulletin 96: 395-414.

Baker, J.A. 1994. Life history variation in female threespine stickleback. pp. 144-187. In: M.A. Bell and S.A. Foster (eds). The Evolutionary Biology of the Threespine Stickleback. Oxford University Press, Oxford, United Kingdom.

Baker, J.A., M.A. Wund, D.C. Heins, R.W. King, M.L. Reyes and S.A. Foster 2015. Life-history plasticity in female threespine stickleback. Heredity 115 : 322-334.

doi: 10.1038/hdy.2015.65

Beverton, R.J.H. 1963. Maturation, growth and mortality of clupeid and engraulid stocks in relation to fishing. Rapports et procès-verbaux des réunions / Conseil permanent international pour l'exploration de la mer 154: 44-67.

Beverton, R.J.H. 1992. Patterns of reproductive strategy parameters in some marine teleost fishes. Journal of Fish Biology 41 (Suppl. B), 137-160.

doi: 10.1111/j.1095-8649.1992.tb03875.x

Beverton, R.J.H. and S.J. Holt 1959. A review of the lifespans and mortality rates of fish in nature, and their relation to growth and other physiological characteristics. pp. 142-180. In:
G.E.W. Wostenholme and M. O'Conner (eds). Ciba Foundation Symposium - The Lifespan of Animals (Colloquia on Ageing), Volume 5. John Wiley and Sons, Oxford, United Kingdom. doi: 10.1002/9780470715253.ch10

Beverton, R.J.H. and S.J. Holt 1966. Manual of methods for fish stock assessment. Part II. Tables of yield function. FAO Fisheries Technical Paper 38: $10+67$ pp. (ver. 1).

Breder, C.M. Jr. and D.E. Rosen 1966. Modes of Reproduction in Fishes. Natural History Press, New York.

Burd, A.C. 1962. Growth and recruitment in the herring of the Southern North Sea. Fishery Investigations London, Series 2: 23.

Charnov, E.L. 1993. Life history invariants. Oxford University Press, Oxford, United Kingdom.

Dudgeon, D. 2003. The contribution of scientific information to the conservation and management of freshwater biodiversity in tropical Asia. Hydrobiologia 500: 295-314. doi: 10.1023/A: 1024666627070

Fernando, M.S.R., N.P.P. Liyanage, S.C. Jayamanne and R.S. Gunasekara 2013. A review of export trade of indigenous freshwater fish species in Sri Lanka and their conservation issues. Proceedings of the Research Symposium of Uva Wellassa University, December 12-13, 2013. Uva Wellassa University, Badulla, Sri Lanka.

Froese, R. and C. Binohlin 2000. Empirical relationships to estimate asymptotic length, length at first maturity and length at maximum yield per recruit in fishes, with a simple method to evaluate length frequency data. Journal of Fish Biology 56: 758-773. doi: 10.1111/j.10958649.2000.tb00870.x

Gayanilo, F.C. Jr. and D. Pauly 1997. FAOICLARM stock assessment tools (FiSAT). Reference manual. FAO Computerized Information Series (Fisheries). FAO, Rome. $262 p$.

Gayanilo, F.C.Jr.; Sparre, P.; Pauly, D., 2005: FAO-ICLARM Stock Assessment Tools II (FiSAT II). Revised Version. User's Guide. FAO Computerized Information Series (Fisheries). No. 8, Revised version. FAO, Rome. 168 p.

Hart, A.M. and G.R. Russ 1996. Response of herbivorous fishes to crown-of-thorns starfish 


\section{R.R.A.R. Shirantha et al.}

Acanthaster planci outbreaks. III. Age, growth, mortality and maturity indices of Acnathurus nigrofuscus. Marine Ecology Progress Series 136: 25-35. doi: 10.3354/meps 136025

Jennings, S., J.D. Reynolds and S.C. Mills 1998. Life history correlates of response to fisheries exploitation. Proceeding of the Royal Society of London B 265: 333-339. doi: 10.1098/rspb.1998.0300

Jensen, A.L. 1996. Beverton and Holt life history invariants result from optimal trade-off of reproduction and survival. Canadian Journal of Fisheries and Aquatic Sciences 53: 820-822. doi: 10.1139/f95-233

Jonsson, B. and J.H. L'abee-Lund 1993. Latitudinal clines in life-history variables of anadromous brown trout in Europe. Journal of Fish Biology 43 (Supplement A): 1-16. doi: 10.1111/j.10958649.1993.tb01175.x

King, M. 2007. Fisheries Biology Assessment and Management. Second Edition. Blackwell Science Ltd., Oxford, United Kingdom. 400 p.

Kortmulder, K. 1987. Ecology and behaviour in tropical freshwater fish communities. Archiv für Hydrobiologie 28: 503-513.

Mims, M.C., J.D. Olden, Z.R. Shattuck and N.L. Poff 2010. Life history trait diversity of native freshwater fishes in North America. Ecology of Freshwater Fish 19: 390-400. doi: 10.1111/j.1600-0633.2010.00422.x

Miththapala, S. 2015. Conservation revisited. Ceylon Journal of Science (Biological Science) 44 (2): 1-26.

doi: http://dx.doi.org/10.4038/cjsbs.v44i2.7347

MOE 2012. The National Red List 2012 of Sri Lanka; Conservation Status of the Fauna and Flora. Ministry of Environment, Colombo, Sri Lanka. viii +476 p.

Pauly, D. 1980. On the interrelationships between natural mortality, growth parameters and mean environmental temperature in 175 fish stocks. Journal du Conseil/ Conseil Permanent International pour l'Exploration de la Mer 39(3): 175-192. doi: 10.1093/icesjms/39.2.175

Pauly, D. 1983. Some simple methods for the assessment of tropical fish stocks. FAO Fisheries Technical Paper 234: 52 p.

Pauly, D. 1984. Fish population dynamics in tropical waters: a manual for use with programmable calculators. ICLARM Studies
Review 8, ICLARM, Manila, The Philippines. $325 \mathrm{p}$.

Roff, D.A. 1992. The evolution of life histories: theory and analysis. Chapman and Hall, London, United Kingdom.

Silva, E.I.L. and E.N.S. Silva 2015. Handbook on Small Hydropower Development and Environment: A Case Study on Sri Lanka. Water Resources Science and Technology, Ragama, Sri Lanka and Asia-Pacific Network for Global Change Research, Kobe, Japan. 113 p. ISBN: 978-955-3920-00-3

(Available online at: https://www.apngcr.org/resources/files/original/ee74f51d9cac10 4230f85b4acfdd4618.pdf

Southwood, T.R.E. 1988. Tactics, strategies and templates. Oikos 52: 3-18.

doi: $10.2307 / 3565974$

Stamps, J.A., M. Mangel and J.A. Phillips 1998. A new look at relationship between size at maturity and asymptotic size. American Naturalist 152: 470-479. doi: 10.1086/286183

Streans, S.C. 1992. The evolution of life histories. Oxford University Press, Oxford, United Kingdom.

Taylor, C.C. 1958. Cod growth and temperature. Journal du Conseil/ Conseil Permanent International pour l'Exploration de la Mer 23: 366-370. doi: 10.1093/icesjms/23.3.366

Vetter, E.F. 1988. Estimation of natural mortality in fish stocks: A review. Fisheries Bulletin 86: 25-43.

Vila-Gispert, A. and R. Moreno-Amich 2002. Lifehistory patterns of 25 species from European freshwater fish communities. Environmental Biology of Fishes 65: 387-400. doi: 10.1023/A: 1021181022360

Welcomme, R.L. 2001. Inland Fisheries: Ecology and Management. Fishing News Books, Blackwell Science, Oxford, United Kingdom. $358 \mathrm{p}$.

Wijeyaratne, M.J.S. and H.H. Costa 1987. The food, feeding and reproduction in an estuarine population of green-back mullet Liza tade (Forsskål) in the Negombo lagoon, Sri Lanka. Ophelia 27(3): 171-180. http://dx.doi.org/10.1080/00785236.1987.10422 020

Wootton, R.J. 1998. Ecology of teleost fishes $2^{\text {nd }}$ Edition. Kluwer Academic Publishers, Dordrecht, The Netherlands. 